\title{
DETERMINATION OF Cu, Fe AND Zn IN SILYBUM MARIANUM SEEDS AFTER DIGESTED USING MICROWAVE OVEN BY FAAS
}

\author{
Cemile ÖZCAN ${ }^{1 *}$ D \\ Kırklareli University, Science and Art Faculty, Chemistry Department, Kırklareli
}

\begin{abstract}
This study, the concentrations of necessary trace and microelements like $\mathrm{Cu}, \mathrm{Fe}$ and $\mathrm{Zn}$ were determined in the Silybum marianum seeds used to medicine purpose for many years. For this intention, the digestion procedure based on closed vessel-assisted microwave oven (MW) was determined a rapid, reliable, and simple digestion method for the flame atomic absorption spectrophotometric (FAAS) analysis of herbal plant. Various periods for different powers and acid mixture of the MW were examined. The obtained data show that the MW is an excellent method because it is fast and results in fewer losses and contaminants. The metal concentrations were of $\mathrm{Fe}>\mathrm{Cu}>\mathrm{Zn}$ for herbal seed, respectively.
\end{abstract}

Keyword: Silybum marianum seeds, Flame atomic absorption spectrophotometry, Microelements

\section{SILYBUM MARIANUM TOHUMLARINDA FAAS İLE MIKKRODALGA FIRIN KULLANILARAK ÇÖZÜNÜRLEŞTİRMEDEN SONRA Cu, Fe ve Zn TAYINI}

\section{$\ddot{O} \mathbf{z}$}

Bu çalışmada, uzun yıllardır ilaç olarak kullanılan Silybum marianum tohumlarında gerekli olan $\mathrm{Cu}, \mathrm{Fe}$ ve $\mathrm{Zn}$ gibi eser elementlerin konsantrasyonları belirlenmiştir. Bu amaçla, tıbbi bitkinin alevli atomik absorpsiyon spektrofotometrik (FAAS) analizi için kapalı sistem destekli mikrodalga fırına (MW) dayalı çözünürleştirme prosedürü hızlı, güvenilir ve basit bir çözünürleştirme yöntemi olarak belirlenmiştir. MW'nin farklı güçleri ve asit karışımı için çeşitli periyotlar incelenmiştir. Elde edilen veriler, MW'nin hızlı olması ve daha az kayıp ve kirletici ile sonuçlanması nedeniyle mükemmel bir yöntem olduğunu göstermektedir. T1bbi tohum için metal konsantrasyonları sirasiyla $\mathrm{Fe}>\mathrm{Cu}>\mathrm{Zn}$ olarak bulundu.

Anahtar kelimeler: Silybum marianum tohumu, Alevli atomic absorpsiyon spektrometresi, Mikro elementler. 
Araştırma

DOI: $10.34186 /$ klujes. 1028780
Özcan/Kırklareli University Journal of Engineering and Science 7-2 (2021) 196-204

Geliş Tarihi:26.11.2021

Kabul Tarihi:12.12.2021

\section{INTRODUCTION}

Herbal materials are either whole plants or parts of medicinal plants in the crude state. They include herbs, fresh juices, gums, fixed oils, essential oils, polyphenols, flavonoids, resins, seeds, several mineral elements, and dry powders of medicinal plants [1-4]. Therefore, metal analysis of them are an essential and significant feature of environmental, biological and chemical research.

The essential trace elements determined in this study $(\mathrm{Cu}, \mathrm{Fe}, \mathrm{Zn})$ have many major functions in the body and are used as commonly in medicinal plants as natural components [5]. $\mathrm{Zn}, \mathrm{Fe}$ and $\mathrm{Cu}$ are the prosthetic group of some metalloenzymes containing super oxide dismutase (SOD), which is an important antioxidant enzyme for cellular protection from reactive oxygen species (ROS) [6,7]. $\mathrm{Cu}$ helps to form hemoglobin in the blood, facilitates the absorption and use of Fe so that blood cells can transport oxygen to the tissues, and assists in regulating the blood pressure and heart rate. $\mathrm{Cu}$ also takes a role in activating more than 30 enzymes including ceruloplasmine, cytochrome oxidase, lysine oxidase, dopamine-hydroxylase, ascorbate oxidase, and tyrosinase, some of which are involved in collagen synthesis. Moreover, copper is necessary for the healthy development of the connective tissue, nerve coverings, and the bones.

$\mathrm{Cu}$ and $\mathrm{Zn}$ are essential for the proper formation and maintenance of bone, cartilage and connective tissue. It contributes to the synthesis of proteins and the genetic material, and helps to produce energy for the body from foods [6]. On the other hand, excessive exposure to these essential metals can cause some diseases such as anemia, liver and kidney damage, stomach and intestinal irritation, aggressive behavior, delinquency and attention disorders [8]. The acceptable daily intake (ADI) recommended by authorized agencies (the FAO/WHO) and the U.S. Recommended Daily Allowances (US RDA) for adults was established as 2.0 to $4.0 \mathrm{mg} /$ day for $\mathrm{Cu}$ [9]. Zn is another micronutrient essential for both plant growth and human health and is involved in the activity of more than 300 metalloenzymes. Zn contributes to the membrane structure and has a central role in the immune system [10-12]. Dietary reference values for Zinc suggested by various sources range from 9.4 to $11.0 \mathrm{mg} /$ day for male adults and from 6.5 to $8.0 \mathrm{mg}$ /day for female adults [12].

$\mathrm{Fe}$ is also a necessary trace element found in almost all living organisms. Moreover, $\mathrm{Fe}$ has an important role transport of heme proteins and in the electron transport through the enzymes [10]. 
In the wet and dry ashing procedures, the sample digestion steps are often the most time-consuming steps of the analysis. These methods are laborious and tedious, often accompanied with a high tendency for contamination. Some authors reported that 15 to 24 hours are required for dry ashing $[13,14]$ or one night (about 12 hours) for both wet and dry ashing $[15,16]$ for the digestion of herbal plants or similar samples. In addition, some potential problems such as incomplete dissolution, precipitation of insoluble analyte, contamination, and loss of some volatile elements can cause contradictory results. With closed vessel microwave digestion, the analysis time, amount of reagents, and risk of contamination or volatile analyte loss can be greatly reduced. So, use of the MW for reliable and rapid sample digestion seems an interesting procedure. A digestion time of several hours for conventional wet digestion can be reduced to a few minutes by using microwave energy [17]. Analytical applications of microwave energy include both a commercial domestic MW [18] for biological samples and a commercial MW equipped with temperature and pressure regulators for biological and environmental matrices [19-21]. The development of the microwaveassisted acid leaching method for extraction of trace elements from products was reported [22]. A mixture or mixtures of $\mathrm{HCl}, \mathrm{HNO}_{3}$, and $\mathrm{HF}$, were used for quantitative extraction of micro- and macro- elements.

We reviewed only macro-elements and trace-elements contents of only seeds of Silybum marianum, which are traditionally used in Turkey for the treatment of sundry ailments, including cancer, diabetes, blood purification (for the health of the liver and the bones), sedative and ulcer (stomach upset). Therefore, in the present work, for determination of these metals $(\mathrm{Cu}, \mathrm{Fe}$ and $\mathrm{Zn}$ ) in medicinal plant seeds, Turkey were used by flame atomic absorption spectrometry (FAAS) after microwave digestion with different acid mixtures.

\section{EXPERIMENTAL}

An Agilent 240 Duo Model flame atomic absorption spectrophotometer (FAAS) equipped and Agilent hollow cathode lamps was used for metal determinations. The applied optimum conditions for FAAS are listed in Table 1. Seed samples were prepared with microwave digestion by Mars 6 (CEM Corporation). All chemicals used were of analytical-reagent grade (Merck quality). Throughout all analytical work, ultrapure water was obtained from water purification system 
(ELGA). In the digestion procedures, concentrated nitric acid (65\%, Merck) and hydrogen peroxide (35\%, Merck) were used. Stock solutions of metals (1000 $\mathrm{mg} \mathrm{L}^{-1}$ ) were prepared from Merck stocks (Darmstadt, Germany). Afterwards, calibration standards of each metal were prepared by appropriate dilution $\left(0.2 \mathrm{~mol} \mathrm{~L}^{-1} \mathrm{HNO}_{3}\right)$ of the stock solution. All glass apparatus (Pyrex) were kept permanently full of $2.5 \%$ nitric acid when not in use.

Table 1: Instrumental operating conditions for FAAS

\begin{tabular}{|c|c|c|c|c|c|c|}
\hline \multirow[b]{2}{*}{ Element } & \multicolumn{6}{|c|}{ Parameters } \\
\hline & $\begin{array}{c}\text { Wavelength } \\
\text { (nm) }\end{array}$ & $\begin{array}{c}\text { HCL curent } \\
(\mathrm{mA})\end{array}$ & 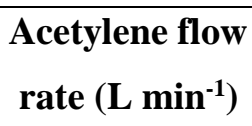 & $\begin{array}{c}\mathrm{N}_{2} \mathrm{O} \text { flow rate } \\
\left(\mathrm{L} \mathrm{min}^{-1}\right)\end{array}$ & $\begin{array}{l}\text { Air Flow rate } \\
\qquad\left(\mathrm{L} \text { min }^{-1}\right)\end{array}$ & $\begin{array}{l}\text { Slit width } \\
\text { (nm) }\end{array}$ \\
\hline $\mathbf{C u}$ & 324.8 & 4.0 & 2.00 & - & 13.50 & 0.5 \\
\hline $\mathbf{F e}$ & 372.0 & 5.0 & 2.00 & - & 13.50 & 0.2 \\
\hline $\mathbf{Z n}$ & 213.9 & 5.0 & 2.00 & - & 13.50 & 0.5 \\
\hline
\end{tabular}

\subsection{Sample collection and preparation}

The herbal seeds of Silybum marianum were collected from its natural habitat the region in Thrace, Turkey during their growing season (June and July) in 2020. The seeds were carefully washed with deionized water and oven-dried at $40^{\circ} \mathrm{C}$. The Silybum marianum samples were powdered using an agate mortar and pestle to reduce the size to fit through a 400-mesh sieve and ground for 20 min to get a fine homogenized mixture.

\subsection{Digestion by MW}

Exactly $2.5-3.0 \mathrm{~mL}$ of the acid mixture of $\mathrm{HNO}_{3} / \mathrm{H}_{2} \mathrm{O}_{2}(2: 1$ or $1: 1)$ was added to $0.5 \mathrm{~g}$ of plant samples. The mixture was placed into a $50{ }^{\circ} \mathrm{C}$ water bath for 30 minutes and stirred occasionally. Then, $1.0 \mathrm{~mL}$ of the same acid mixture was added and the mixture transferred into a $75 \mathrm{~mL}$ Teflon express vessel in a MW using a program in one stages (time $15 \mathrm{~min}$, temperature $120{ }^{\circ} \mathrm{C}$, power $450 \mathrm{~W}$ or $600 \mathrm{~W}$ or $800 \mathrm{~W}$ ). The Teflon vessel was closed and placed inside the MW. Radiation was applied for 15 minutes at selected power. If necessary, minimum volume (approximately 0.5 $\mathrm{mL}$ ) of the same digestion mixture was added. 
After 10 minutes of cooling, $10 \mathrm{~mL}$ of ultra pure water was added, and the solution transferred into a falcon tube. The final volume was completed to be about $20 \mathrm{~mL}$. After centrifugation, the clear solution was analyzed by FAAS. The blank digests were carried out in the same way for each digestion. Three different portions of each sample were digested and the average value was calculated for the same sample.

\subsection{Method Validation}

The samples were at least five repetitions were chosen for analysis to get their mean and standard deviation values by FAAS. LODs were calculated from standard deviations of five repeat analyzes of samples. The limit of detection and limit of quantification were computed by the formulas;

LOD $=3 \times$ Standard Deviation

and

LOQ $=10 \times$ Standard Deviation

The standard reference material (Apple and Spinach) was analyzed as certified a reference material to calculate the reliability and accuracy of the method:

$\%$ Recovery $=($ Experimental Value/Certified Value $) \times 100$

The obtained concentrations of trace metals were ten times higher than their LOD values, so we quantified the above trace elements by $95 \%$ confidence limits using FAAS. The calculated RSD $(\%)$, LOD, LOQ, linearity $(\mathrm{y}=\mathrm{mx}+\mathrm{n})$, correlation coefficient values $\left(\mathrm{R}^{2}\right)$ were shown in the Table 2 , which validating the precision of the method.

Table 2: Validation process values of the analyzed metals for validating the precision of the method

\begin{tabular}{|l|l|l|l|l|l|}
\hline & Linearity & $\mathbf{R}^{\mathbf{2}}$ & $\begin{array}{l}\text { LOD } \\
(\mathbf{m g} / \mathbf{L})\end{array}$ & $\begin{array}{l}\text { LOQ } \\
(\mathbf{m g} / \mathbf{L})\end{array}$ & RSD\%< \\
\hline $\mathbf{C u}$ & $0.115 \mathrm{X}-0.0031(0.05-2.5 \mathrm{mg} / \mathrm{L})$ & 0.9994 & 0.0147 & 0.049 & 0.4 \\
\hline $\mathbf{F e}$ & $0.0586 \mathrm{X}+0.0026(0.1-5.0 \mathrm{mg} / \mathrm{L})$ & 0.9999 & 0.018 & 0.060 & 1.1 \\
\hline $\mathbf{Z n}$ & $2.0643 \mathrm{x}+0.0522(0.05-0.5 \mathrm{mg} / \mathrm{L})$ & 1.000 & 0.0135 & 0.045 & 0.9 \\
\hline
\end{tabular}




\section{CONCLUSION}

This study shows which the determination of trace metals $(\mathrm{Cu}, \mathrm{Fe}$ and $\mathrm{Zn})$ in Silybum marianum by FAAS. To solve the samples were used methods closed vessel microwave digestion. The methods had been validated for the determination of metals in medicinal plants. But, wet decomposition has been performed in open systems for many years. In our study, the sensitivity of analyses was similar for all methods. Closed-vessel microwave (MW) digestion from these methods is rapid and simple. The best result of digestion was obtained MW higher than the dry ashing. In addition to, the best method for samples was observed with 1/1 acid mixture by MW digestion.

Some trace elements are essential for human and plant growth under the permissible limits. However, if trace metal concentrations exceed the critical levels, then they are toxic to both humans and plants [23-25]. Major metal concentrations were in the order of $\mathrm{Fe}>\mathrm{Cu}>\mathrm{Zn}$ for Silybum marianum. The highest mean levels of $\mathrm{Cu}, \mathrm{Fe}$ and $\mathrm{Zn}$ were detected in plant seeds.

The results of MW digestion were given in Table 3. It can be seen that the $\mathrm{Cu}, \mathrm{Fe}$ and $\mathrm{Zn}$ concentrations are in range of $62.8-190 \mathrm{mg} \mathrm{kg}^{-1}, 1974-3588 \mathrm{mg} \mathrm{kg}^{-1}$ and $56.5-115 \mathrm{mg} \mathrm{kg}^{-1}$, respectively in 1/1 and 2/1 acid mixture in MW digestion for seed.

Table 3: Comparison of MW digestion Method for Metals Determination in the plant seeds $\left(\mathrm{mg} \mathrm{kg}^{-1}\right)$

\begin{tabular}{|c|c|c|c|c|c|}
\hline $\begin{array}{c}\text { Herbal } \\
\text { plant }\end{array}$ & $\begin{array}{c}\text { Power } \\
\text { (Watt) }\end{array}$ & $\begin{array}{c}\mathbf{H N O}_{3} / \mathbf{H}_{2} \mathbf{O}_{2} \\
\text { acid mixture }\end{array}$ & $\mathbf{C u}$ & $\mathbf{F e}$ & $\mathbf{Z n}$ \\
\hline \multirow{4}{*}{$\begin{array}{c}\text { Silybum } \\
\text { marianum }\end{array}$} & 450 & $1 / 1$ & $79.7 \pm 2.6$ & $2091 \pm 11$ & $60.1 \pm 5.2$ \\
\cline { 2 - 6 } & 450 & $2 / 1$ & $62.8 \pm 5.3$ & $1974 \pm 77$ & $56.5 \pm 4.3$ \\
\cline { 2 - 6 } & 600 & $1 / 1$ & $157 \pm 8$ & $2928 \pm 24$ & $81.2 \pm 2.7$ \\
\cline { 2 - 6 } & 800 & $2 / 1$ & $108 \pm 4$ & $2653 \pm 56$ & $76.8 \pm 6.4$ \\
\cline { 2 - 6 } & 800 & $1 / 1$ & $190 \pm 5$ & $3588 \pm 37$ & $115 \pm 8$ \\
\hline
\end{tabular}


The procedure was applied for the analytes determination in the plant seed with satisfactory results (recoveries $>95 \%$ and relative standard deviation's (RSD) lower than 4\%). The Silybum marianum was found to quite high concentration of Fe and $\mathrm{Zn}$. Moreover, to prevent and treat iron deficiency, exogenous inorganic iron supplementation can used as food supplement in the industry.

\section{ACKNOWLEDGMENTS}

The author thanks the Kirklareli University Research Foundation for their supports (DPT2010K121120; KLUBAP-120; KLUBAP-198).

\section{REFERENCES}

[1] WHO guidelines for assessing quality of herbal medicines with reference to contaminants and residues, World Health Organization, ISBN 978-92-4-159444-8, 2007.

[2] Ozcan, C., Yaman, M., Determination of Myricetin in Medicinal Plants by High-Performance Liquid Chromatography, Instrumentation Science \& Technology, 43(1), 44-52, 2015.

[3] Ozcan, C., Yaman, M., Determination of kaempferol in Rosa canina, Urtica dioica, Terebinthina chica and Portulace oleracea by HPLC-MS, Asian Journal of Chemistry, 25(17), 9758-9762, 2013.

[4] Ozcan, C., Dilgin, Y., Yaman, M., Determination of quercetin in medicinal plants such as rose hip (Rosa canina), nettle (Urtica dioica), terebinth (Terebinthina chica) and purslane (Portulace oleracea) using HPLC-MS method, Asian Journal of Chemistry, 24(8), 3396-3400, 2012.

[5] Feinendegen, L. E., Kasperek, K., Medical aspects of trace element research, Trace Elem. Anal. Chem Med. Biol. 1-17, 1980.

[6] Mertz, W., Trace elements in human and animal nutrition, Vol. 1-2, San Diego, CA, USA, Academic Press, 1987.

[7] White, P. J., Broadley M. R., Biofortification of crops with seven mineral elements often lacking in human diets-iron, zinc, copper, calcium, magnesium, selenium and iodine, New Phytologist, 182(1), 49-84, 2009.

[8] Ozcan, C., Kırklareli İl Merkezinde Yetişen Bazı Bitki Türlerinin Eser Element Analizleri, Electronic Journal of Vocational Colleges, 3(1), 184-193, 2013.

[9] Noel, L., Leblanc, J. C., Guerin, T., Determination of several elements in duplicate meals from catering establishments using closed vessel microwave digestion with inductively coupled plasma 
mass spectrometry detection: estimation of daily dietary intake, Food Additives \& Contaminants, 20(1), 44-56, 2003.

[10] Prasad, M. N. V., Trace elements as contaminants and nutrients: Consequences in ecosystems and human health, ISBN 978-0-470-18095-2, 2008.

[11] Çelik, A., Kartal, A. A., Akdoğan, A., Kaska, Y., Determining the heavy metal pollution in Denizli (Turkey) by using Robinio pseudo-acacia L., Environment International, 31, 1052005.

[12] Ozturk, L., Yazici, M. A., Yucel, C., Torun, A., Cekic, C., Bagci, A., Ozkan, H., Braun, H-J., Sayers, Z., Cakmak, I., Concentration and localization of zinc during seed development and germination in wheat, Physiologia Plantarum 128, 144-152, 2006.

[13] WHO, 1996. World Heath Organization, Geneva, Switzerland, EB109/33. 2001.

[14] Del Río-Celestino M., Font R., Moreno-Rojas R., De Haro-Bailón A., Uptake of lead and zinc by wild plants growing on contaminated soils, Industrial Crops and Products, 24(3), 230-237, 2006.

[15] Karadjova, I., Izgi, B., Gucer, S., Fractionation and speciation of $\mathrm{Cu}, \mathrm{Zn}$ and $\mathrm{Fe}$ in wine samples by atomic absorption spectrometry, Spectrochimica Acta, Part B: Atomic Spectroscopy,57(3), 581-590, 2002.

[16] Oliva, S.,R., Raitio, H., Mingorance, M. D., Comparison of two wet digestion procedures for multi-element analysis of plant samples, Communications in Soil Science and Plant Analysis, 34, 2913-2923, 2003.

[17] Hacisalihoglu, G., Kochian, L. V., How do some plants tolerate low levels of soil zinc? Mechanisms of zinc efficiency in crop plants, New Phytologist, 159, 341-350, 2003.

[18] Demirezen, D., Aksoy, A., Heavy Metal Levels in Vegetables in Turkey are within safe limits for $\mathrm{Cu}, \mathrm{Zn}$, Ni and exceeded for $\mathrm{Cd}$ and Pb, Journal of Food Quality, 29, 252-265, 2006.

[19] Colak Esetlili, B., Pekcan, T., Çobanoğlu, Ö., Aydoğdu, E., Turan, S., Anaç, D., Essential plant nutrients and heavy metals concentrations of some medicinal and aromatic plants, Journal of Agricultural Sciences, 20, 239-247, 2014.

[20] Smith F.E., and Arsenault E.A. Microwave-assisted sample preparation in analytical chemistry, Talanta, 43(8), 1207-1268, 1996.

[21] Ozcan, C., Balkan, S., Multi-residue determination od organochlorine pesticides in vegetables in Kirklareli, Turkey by gas chromatography-mass spectrometry, Journal of Analytical Chemistry, 72(7), 761-769, 2017. 
[22] Baranowska, I., Srogi, K., Wlochowicz, A., Szczepanik, K., Determination of heavy metal contents in samples of medicinal herbs, Polish Journal of Environmental Studies, 11(5), 467-471, 2002.

[23] Divrikli, U., Horzum, N., Soylak, M., Elci, L., Trace heavy metal contents of some spices and herbal plants from western Anatolia, Turkey, International Journal of Food Science \& Technology, 41, 712-716, 2006.

[24] Kaya, G., Ozcan, C., Yaman, M., Flame atomic absorption spectrometric determination of Pb, $\mathrm{Cd}$, and $\mathrm{Cu}$ in Pinus nigra L. and Eriobotrya japonica leaves used as biomonitors in environmental pollution, Bulletin of environmental contamination and toxicology, 84(2), 191-196, 2010.

[25] Ozcan, C., Yaman, M., Determination of $\mathrm{Ni}, \mathrm{Pb}$ and $\mathrm{Cu}$ in plant and soil samples to monitor pollution extent: comparison of Kirklareli-Elazig cities, Turkey, Fresenius Environmental Bulletin 27 (3), 1319-1328, 2018. 